\title{
Effect of an intervention in Physical Education classes on health related levels of physical fitness in youth
}

\author{
Efeito de um programa de Educação Física Escolar nos níveis de aptidão \\ física relacionada à saúde de jovens
}

Luciane Canto Vargas de Oliveira', Fernando Cesar Camargo Braga', Vanilson Batista Lemes', Arieli Fernandes Dias', Caroline Brand', Júlio Brugnara Mello', Anelise Reis Gaya', Adroaldo Cezar Araujo Gaya'

\begin{abstract}
The aim of this study was to verify the effect of an intervention program during Physical Education (PE) classes on levels of physical fitness related to health in youth. This is a pre-experimental study. The students ( 40 boys and 48 girls) were conveniently selected from a private school in Southern Brazil. Cardiorespiratory fitness was assessed through the six-minute test, recorded in meters $(\mathrm{m})$, flexibility through the sit-andreach test, recorded in centimeters $(\mathrm{cm})$, abdominal strength/ resistance through repetitions in one minute (rep) and body mass index (BMI) through the [mass/height $\left.{ }^{2}\right]$ equation. The intervention program was conducted in PE classes, often twice a week, during an entire school year. Data analysis was performed using descriptive analysis, Student's t-test and repeated measures ANOVA, taking into consideration $p<0.05$. The PE program promoted improvement in cardiorespiratory fitness for boys (pre-test: $1123.0 \mathrm{~m} \pm 197.0 \mathrm{~m}$; post-test: $1247.2 \mathrm{~m} \pm 139.6 \mathrm{~m}$; $\mathrm{p}=0.002$ ) and girls (pre-test: $940.7 \mathrm{~m} \pm 75.0 \mathrm{~m}$; post-test: $1028.7 \mathrm{~m} \pm 67.3 \mathrm{~m} ; \mathrm{p}=0.001)$; abdominal strength/resistance for boys (pre-test: 46.1 rep \pm 10.1 rep; post-test: 53.9 rep \pm 10.4 rep; $\mathrm{p}=0.001)$ and girls (pre-test: 36.4 rep \pm 8.3 rep; post-test: 44.0 rep \pm 6.1 rep; $\mathrm{p}=0.001$ ); and flexibility for boys (pre-test: $22.7 \mathrm{~cm}$ $\pm 8.1 \mathrm{~cm}$; post-test: $27.6 \mathrm{~cm} \pm 7.2 \mathrm{~cm} ; \mathrm{p}=0.006$ ) and girls (pre-test: $32.0 \mathrm{~cm} \pm 6.2 \mathrm{~cm}$; post-test: $34.8 \mathrm{~cm} \pm 6.4 \mathrm{~cm} ; \mathrm{p}=0.032$ ). There weren't changes in mean BMI values. Therefore, it's considered that the PE program aimed at health promotion through physical fitness can improve the indicators of cardiometabolic and muscle-skeletal health in students.
\end{abstract}

\section{Keywords}

Muscle Strength; Exercise; Body Mass Index.

\section{Resumo}

O objetivo deste estudo foi verificar o efeito de um programa de intervenção nas aulas de Educação Física Escolar sobre os níveis de aptidão física relacionada à saúde de jovens. Trata-se de um estudo pré-experimental. Os estudantes (40 meninos e 48 meninas) foram selecionados por conveniência em uma escola privada do sul do Brasil. Foram avaliados a aptidão cardiorrespiratória através do teste de seis minutos, anotado em metros $(m)$, flexibilidade através do teste de sentar e alcançar, anotado em centímetros (cm), forçal resistência abdominal através de repetições em um minuto (rep) $e$ indice de massa corporal (IMC) através da equação massa/estatu$\mathrm{ra}^{2}$. O programa de intervenção foi realizado nas aulas de Educação Física, com frequência de duas vezes semanais, durante um ano letivo. Para análise dos dados recorreu-se a análise descritiva, teste $t$ de Student e ANOVA de medidas repetidas, levando em consideração um $p<0,05$. O programa de Educação Física Escolar promoven melhoria da aptidão cardiorrespiratória dos meninos (pré: 1123,0m $\pm 197,0 m$; pós: $1247,2 m \pm 139,6 m$; p: 0,002) e meninas

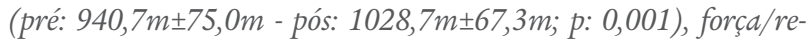
sistência abdominal dos meninos (pré: 46,1 rep $\pm 10,1$ rep - pós: 53,9 rep \pm 10,5 rep; p: 0,001) e meninas (pré: 364 rep $\pm 8,3$ rep - pós: 44,0 rep $\pm 6,1$ rep; $p: 0,001$ ) eflexibilidade dos meninos: (pré: 22,7cm \pm 8 ,-

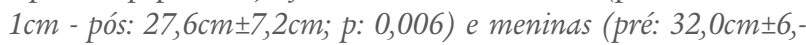
$2 \mathrm{~cm}$ - pós: $34,8 \mathrm{~cm} \pm 6,4 \mathrm{~cm} ; \mathrm{p}: 0,032)$. Não howveram variações nos valores médios do IMC. Portanto, considera-se que o programa de educação física escolar direcionado à promoção da saúde, através da aptidão física pode melhorar os indicadores de saúde cardiometabólica e musculoesquelética em estudantes.

\section{Palavras-chave}

Força muscular; Exercício; Indice de massa corporal.

\section{Introduction}

Physical Education classes (PE) are known as favora-

1 Program of Science of Human Movement, School of Physical Education,

Physiotherapy and Dance (SPEFD), Federal University of Rio Grande do Sul (UFRGS). Porto Alegre, RS, Brazil. ble to increase levels of physical activity in children and adolescents, through the intervention in health promotion and prevention of chronic non-communicable diseases ${ }^{1}$. However, studies have shown that opportunities for physical activity in the school con- 
text are declining ${ }^{2}$. Moreover, it is evident that such population is not sufficiently active, not even during PE, preventing these activities' benefits for health ${ }^{2-4}$.

As a consequence of such phenomena, the levels of cardiorespiratory fitness (CF), flexibility and strength/muscular resistance of adolescents are below the recommendation, while the nutritional profile is higher. Under this perspective, it is understood that youth is in a zone of classification indicating a possible health risk $^{5,6}$. Brazilian studies show approximately $30 \%$ to $50 \%$ of adolescents in those health risk zones for all components of physical fitness related to health ${ }^{5-7}$. It is noted, however, that most youth at health risk is seen in $\mathrm{CF}^{5,6}$.

Such results are worrying in the perspective that there is elevated association between the components of physical fitness and health risk factors in childhood and adolescence ${ }^{8-10}$. That fact has been responsible for the early increase in prevalence of disease such as type 2 diabetes, obesity, hypertension, and osteoporosis, ${ }^{7,810-14}$.

Under the perspective to modify the scenario, some studies have highlighted the importance of different intervention programs in the school environment ${ }^{15,16}$. Such studies have suggested that physical activity should be practiced during classes, at recess, in PE and in non-school hours ${ }^{15}$. In the same way, this study presents a PE intervention with the aim to promote health through good levels of physical fitness. This was accomplished through a proposal in which 15 minutes of exercises were added, called body formation. It is important to highlight the difficulty to find studies with school aged children and this aim in Brazilian literature.

In this context, the hypothesis is that $\mathrm{PE}$ aiming at health promotion with 15 minutes of body formation has significant effects in the levels of physical fitness and, consequently, is effective in reducing the health risks to school aged children ${ }^{16,17}$. Therefore, the aim of this study was to verify the effect of an intervention program in PE on the levels of physical fitness related to health in youth.

\section{Methods}

\section{Design and sample}

This is a pre-experimental study ${ }^{18}$ with one single intervention group (IG). Sample was composed by 40 boys and 48 girls in the first year of high school, with mean age of 14 years (Table 1), selected by convenience in a private school in the city of Porto Alegre, Brazil. These students were from two classes, both with the same number of weekly lessons and in the same period (morning). The students in the final sample participated in the intervention throughout the year and assessments in the beginning and end of the school year. This study was approved by the ethics committee of the Federal University of Rio Grande do Sul (nº 501.631).

\section{Intervention}

In total, the IG participated in 80 PE classes during the months of February and March. The classes were held two times a week, in the same period as other courses and with duration of 45 minutes. The children remained with the same teachers throughout the year and boys were separated from girls, each group with a different teacher. The teachers were licensed in Physical Education and master students at the Federal University of Rio Grande do Sul. These teachers were also responsible for the interventions in the school, and were part of the research team. The aims developed for PE classes were elaborated by those teachers and were in agreement with the political and pedagogical project of the school. The intervention program was planned with structured lessons and divided into three phases, as shown in figure 1 . 


\begin{tabular}{|l|l|l|}
\hline Structure of the class & Characteristics & Time \\
\hline Introduction & Warm up with active and passive stretching, short runs, or games & 10 minutes \\
\hline Main & $\begin{array}{l}1^{\text {st }} \text { moment: body build-up, consisting in strength, resistance, maximum } \\
\text { strength, explosive strength and aerobic resistance exercises. Strength } \\
\text { exercises were planned to develop main muscular groups, such as: push- } \\
\text { ups, pull-ups, sit-ups, triceps, squats, jumps, jumping squats. For aerobic } \\
\text { resistance, continuous and interval running, running with ball, and other. }\end{array}$ & \\
\cline { 2 - 3 } & $\begin{array}{l}2^{\text {nd }} \text { moment: sports: basic movements of sports alternating with games, } \\
\text { highlighting rules and tactical schemes. }\end{array}$ & 15 minutes \\
\hline Conclusion & $\begin{array}{l}\text { A few moments for reflection on the contents presented in class, or the } \\
\text { behavior and performance presented by the students, or even a final } \\
\text { stretch. }\end{array}$ & 5 minutes \\
\hline
\end{tabular}

FIGURE 1 - Model used in Physical Education classes.

\section{Instruments and procedures}

The assessments of the IG were conducted the moment previous to the beginning of the intervention program (pre-test) and at the end of the school year (post-test) and the Physical Education teachers responsible for the intervention managed the procedures. For each assessment (pre-test and post-test) two periods for each class were necessary. For the physical fitness assessment, norms were dictated according to PROESP-Br ${ }^{19}$.

\section{Cardiorespiratory fitness}

The CF was assessed through the run/walk 6-minute test. The protocol consists in dividing the students in groups adequate to the number of evaluators, in this case, 10 students. The children were informed about the time for execution of the test emphasizing the fact that they should run/walk as much as they could, avoiding sprints versus longs walks. Besides, they were informed when half the test was completed ( 3 minutes) and at the last minute. At the end of the test, a signal (whistle) sounds to let students know to interrupt the run, remaining where they are at the moment of the signal until the distance has been marked. The final measurement is registered in meters, with one decimal point.

\section{Nutritional status}

Height was measured with a measuring tape attached to the wall and extended from bottom to the top. Students were in vertical position, with feet and torso touching the wall. Body mass was measured with a scale (Plenna Wave MEA-07707) with 100-gram precision, the students wearing light clothing and bare feet. The height and body mass were noted in centimeters and kilograms with one decimal point. The body mass index (BMI) was calculated dividing the body mass measure in kilograms by squared height in meters.

\section{Flexibility}

The flexibility was assessed through the seat and reach test. The protocol for this test consists in extending a measure tape on the ground. In the 38 centimeters mark, a 30 centimeters tape was placed, perpendicular. Students were barefoot and ankles should touch the tape at the $38 \mathrm{~cm}$ and be apart $30 \mathrm{~cm}$. With stretched knees and superposed hands, the students slowly inclined and extended hands to the front as far as possible. The student must remain in that position as long as needed to note the distance. Two tries were allowed and the results noted in centimeters, with one decimal point. 


\section{Abdominal strength/resistance}

The sit-up test was used to assess abdominal strength. The student should be facing up sitting on the ground, with knees bent to 45 degrees and arms crossed over the chest. The teacher holds the students' feet with both hands, fixating them to the ground. At the signal, the student flexes the torso until the elbows touch their thighs, returning to the initial position. The student had to repeat as many times as possible during one minute. The number of repetitions noted the result.

\section{Data analysis}

Initially, a descriptive analysis was performed to identify characteristics of the sample, presented in means and standard deviations, stratified by gender and group. For normality of variables, Kolmogorov-Smirnov test was used and to verify homogeneity of variance (intra group) the Levene test was used. For difference between genders for variables age, BMI, flexibility, abdominal strength/resistance and cardiorespiratory fitness in the pre-test phase, the t-student test for independent samples was conducted. The effect of the intervention program under the variables of physical fitness was tested considering the effect of time in the IG (ANOVA for repeated measures to two factors, effect of time testes separately for each gender), through comparison of mean values between pre and post-tests. All of the analyses were completed calculating Cohen's $\mathrm{d}$ for effect size ${ }^{20}$, considering: low effect (0-0.6), moderate (0.61-1.2) and high (>1.21). For all analyses, software SPSS 20.0 was used considering significance at 0.05 .

\section{Results}

Table 1 presents pre-test sample characteristics. Mean values were significantly different between boys and girls in cardiorespiratory fitness, abdominal strength and flexibility. Mean flexibility for girls was higher than for boys, nonetheless, abdominal strength/resistance and cardiorespiratory fitness was lower when compared to boys.

TABLE 1 - Sample description according to the analyzed variables and comparison between genders on pre-test.

\begin{tabular}{lcccc}
\hline & Boys (40) & Girls (48) & & \\
\cline { 2 - 5 } & Mean \pm SD & Mean \pm SD & $t(1.86)$ & $p$ \\
\hline Age (years) & $14.23 \pm 0.6$ & $14.10 \pm 0.4$ & 1.0 & 0.28 \\
\hline BMl (Kg/m²) & $21.35 \pm 4.2$ & $20.46 \pm 2.8$ & 1.1 & 0.26 \\
\hline CF $(\mathrm{m})$ & $1123.07 \pm 197.0$ & $940.73 \pm 75.0$ & 5.5 & 0.001 \\
\hline Abdominal (rep) & $46.15 \pm 10.1$ & $36.40 \pm 8.3$ & 5.0 & 0.001 \\
\hline Flexibility (cm) & $22.78 \pm 8.1$ & $32.08 \pm 6.2$ & 5.9 & 0.001 \\
\hline
\end{tabular}

BMI: body mass index; CF: cardiorespiratory fitness; SD: standard deviation. t: student's t test value; $\mathrm{p}<0.05$ : significant difference between gender.

Table 2 presents comparison between pre and post-test of physical fitness indicators related to health for boys and girls. An effect for PE program was identified in all components of physical fitness. The CF of girls increased significantly $(\mathrm{F}(1.94)=35.9 ; \mathrm{p}=0.001 ; \mathrm{d}=1.23)$, followed by abdominal strength/resistance. For boys, $\mathrm{CF}$ as well as abdominal strength/resistance increased $(\mathrm{F}(1.78)=10.5 ; \mathrm{d}=0.72$ and $\mathrm{F}(1.78)=11.2 ; \mathrm{d}=0.75$, respectively). In terms of flexibility, the effect for boys $(F(1.78)=7.8 ; d=0.62)$ was higher than for girls $(F(1.94)=7.8 ; d=0.40)$. There was no significant variation between the mean of BMI for both genders. 
TABLE 2 - Comparison between pre-test and post-test of physical fitness indicators for each gender.

\begin{tabular}{|c|c|c|c|c|c|}
\hline & \multicolumn{5}{|c|}{ Boys } \\
\hline & $\begin{array}{c}\text { Pre-test } \\
\text { Mean } \pm S D\end{array}$ & $\begin{array}{c}\text { Post-test } \\
\text { Mean } \pm \text { SD }\end{array}$ & $F(1.78)$ & Cohen's d & $\mathrm{p}$ \\
\hline BMI $\left(\mathrm{kg} / \mathrm{m}^{2}\right)$ & $21.35 \pm 4.27$ & $22.12 \pm 4.30$ & 0.65 & 0.17 & 0.42 \\
\hline$C F(m)$ & $1123.0 \pm 197.0$ & $1247.2 \pm 139.6$ & 10.5 & 0.72 & 0.002 \\
\hline Flexibility (cm) & $22.77 \pm 8.11$ & $27.60 \pm 7.23$ & 7.8 & 0.62 & 0.006 \\
\hline \multirow[t]{3}{*}{ Abdominal (rep) } & $46.15 \pm 10.15$ & $53.90 \pm 10.49$ & 11.2 & 0.75 & 0.001 \\
\hline & \multicolumn{5}{|c|}{ Girls } \\
\hline & $\begin{array}{c}\text { Pre-test } \\
\text { Mean } \pm \text { SD }\end{array}$ & $\begin{array}{c}\text { Post-test } \\
\text { Mean } \pm \text { SD }\end{array}$ & $F(1.94)$ & Cohen's d & $p$ \\
\hline BMI $\left(\mathrm{kg} / \mathrm{m}^{2}\right)$ & $20.48 \pm 2.89$ & $21.31 \pm 2.85$ & 2.12 & 0.28 & 0.149 \\
\hline$C F(m)$ & $940.7 \pm 75.0$ & $1028.7 \pm 67.3$ & 35.9 & 1.23 & 0.001 \\
\hline Flexibility (cm) & $32.08 \pm 6.21$ & $34.89 \pm 6.43$ & 4.7 & 0.40 & 0.032 \\
\hline Abdominal (rep) & $36.39 \pm 8.32$ & $44.00 \pm 6.16$ & 25.8 & 1.03 & 0.001 \\
\hline
\end{tabular}

BMI: body mass index; CF: cardiorespiratory fitness; SD: standard deviation. Kg/m2: kilograms/squared meter; cm: centimeters; rep: repetitions in 1 minute; m: meters.

\section{Discussion}

The results of the present study show significant effect of a PE program in the levels of CF, abdominal strength/resistance and flexibility of boys and girls. These findings are evidence of the importance of PE classes in the promotion of health of youth and the need for schools to offer classes that include regular physical activity ${ }^{1}$. Moreover, considering there is high prevalence of youth with low physical fitness levels and there is direct relation between those components and the risk for cardiometabolic health ${ }^{22}$ as well as muscle-skeletal ${ }^{28}$, we suggest that, beyond the increase in levels of physical activity in the school environment, an emphasis is given to physical fitness as one of the aims of PE classes. Thus, more than being associated to health benefits, physical fitness can be considered as an important tool for assessment, as long as it is contextualized and according to the proposed aims, also taking into account the physiological diversity of the students ${ }^{21}$.

The present study indicated a positive effect of the intervention in levels of CF, one of the main indicators of risk for cardiometabolic health in youth ${ }^{8}$. Another important factor of the results is that the low levels of CF found in youth can be one of the main risk factors for cardiovascular events during adulthood ${ }^{22}$, proving this variable deserves attention during the years of adolescence. In addition, many studies have emphasized the prediction of risk factors for cardiometabolic health through CF in youth ${ }^{10,13,23,24}$. Therefore, this study points out an important result for cardiometabolic health in youth, with findings in agreement with a study of similar methodological characteristics ${ }^{25}$, using the same volume of exercise per week, progressively increasing the intensity of classes obtaining significant effects on CF levels.

Thus, it is evident that PE classes may have an effect in one of the main indicators of risk for the most prevalent diseases in the population. Nonetheless, the PE program was not effective on BMI, another indicator of risk for cardiometabolic health. This result can be explained by the lack of control in food consumption, as well as the limitation the BMI itself presents, since in adolescents this variable should be cautiously analyzed once muscular body mass could be gained during an intervention and lead to wrong interpretation of the possible relation between growth and development indicators in youth ${ }^{1}$. However, it is important to highlight that other studies have shown a low effect of intervention programs in body 
composition ${ }^{15-17,26,27}$. In fact, research has presented positive results in levels of physical fitness and metabolic parameters ${ }^{15-17}$, indicating effectiveness of the interventions on those aspects even when there is no decrease in BMI, in agreement with the present findings.

Also, a significant effect of the PE program on muscle-skeletal fitness was observed. These results are similar to those found in other studies focused on the need for physical exercise in the promotion of better muscular health conditions ${ }^{26,27}$. Flexibility of boys and girls increased after the program. However, the effects had different dimensions for both genders. While the girls had a higher effect in the number of sit-ups in one minute, boys presented higher effect in flexibility. These facts can be explained by the higher values for flexibility of girls in the beginning of the study and sit-ups for boys, that is, the lower the muscle-skeletal fitness during pre-test, the higher the effect of the intervention.

Such results are relevant considering that the literature indicates lower levels of flexibility inversely associated to the presence of pain in the lumbar back region in youth ${ }^{28}$. Some studies indicated that girls present more adequate levels of flexibility than boys ${ }^{26,27,28}$ and also are more likely to engage in exercise to improve flexibility, therefore, we suggest future interventions take this into consideration as well as other strategies to reach a positive effect on the flexibility for boys.

Our findings corroborate with the literature and demonstrate the relevance of planning PE classes ${ }^{16,17,29}$. The main focus of the intervention during PE classes was to allow changes in the levels of health in youth, a result that was reached, especially in levels of CF, abdominal strength/resistance and flexibility for girls. Therefore, an intervention was conducted with organized classes with the central aim to promote health. The structure of the classes was divided into three categories of movement: warm-up/stretching, functional training circuit and sports.

Nonetheless, the present studies has limitations: sexual maturation of the participants was not assessed; there was no objective control of the intensity of physical activity and other activities performed outside of school were not controlled; and the fact that there was no control group did not allow us to identify the interaction between time and group on the post-test period. This makes impossible to compare the intervention program from this study and regular PE classes from other schools, as well as if the effect of such interactions could lead to differences in physical fitness.

Moreover, it is important to highlight that few studies published in Brazil show results from an intervention with Physical Education and physical activity for health in levels of physical fitness of children and youth ${ }^{30}$. The studies show the importance of having a program directed at this goal, suggesting subjects have considerable positive changes in physical fitness for health ${ }^{30}$. As such, the present study collaborated to the knowledge on this subject, in agreement with many other studies in European and North American countries that highlighted PE classes as support of high relevance for public health programs ${ }^{15-17}$.

At last, it is suggested that PE through the teaching of different manifestations of body culture and human movement, may be a health promoter, since at times the school is the only space where school-aged children have access to physical activity. To conclude, our results are in agreement with the hypothesis that a PE program directed at promotion of health, through physical fitness, can result in significant improvement in cardiometabolic and muscle-skeletal health indicators in youth.

\section{Funding source}

National Counsel for Scientific and Technological Development (CNPq). 


\section{Author Contributions}

L. C. V. de Oliveira and F. C. C. Braga participated in the study design, data collection, application of the intervention, data analysis, discussion of the results and manuscript writing; V. B. Lemes, A. D. Fernandes, C. Brand and J. B. Mello participated in data collection, tabulation and data analysis, results interpretation and discussion, and manuscript writing. A. R. Gaya and A. C. A. Gaya participated in the study design, critical review and orientation of the research project, data analysis, discussion of results, writing and critical review of the final version.

\section{References}

1. Sallis JF, McKenzie TL, Beets MW, Beighle A, Erwin H, Lee S. Physical Education's Role in Public Health: Steps Forward and Backward Over 20 Years and HOPE for the Future. Res Q Exerc Sport. 2012 Jun;83(2):125-35.

2. Kremer MM, Reichert FF, Hallal PC. Intensity and duration of physical exertion in Physical Education classes. Rev Saude Publica. 2012;46(2):320-6.

3. Kahan D, Mckenzie TL. The Potential and Reality of Physical Education in Controlling Overweight and Obesity. Am J Public Health. 2015;105(4):4-11.

4. Pate RR, Davis MG, Robinson TN, Stone EJ, McKenzie TL, Young JC. Promoting physical activity in children and youth: a leadership role for schools: a scientific statement from the American Heart Association Council on Nutrition, Physical Activity, and Metabolism (Physical Activity Committee) in collaboration with the Co. Circulation. United States; 2006 Sep;114(11):1214-24.

5. Minatto G, Santos Silva DA, Pelegrini A, Fidelix YL, da Silva AF, Petroski EL. Cardiorespiratory fitness, sociodemographic indicators and nutritional status in adolescents. Rev Bras Med do Esporte. 2015;21(1):12-6.

6. Gaya AR, Cézane Priscila R, Éboni Marília R, Silvia Isabel Rech F, Daniel P, Adroaldo Cezar Araújo G, et al. Cumulative incidence of youth obesity is associated with low cardiorespiratory fitness levels and with maternal overweight. Mot Rev Educ Física. 2015;21:407-14.

7. Flores LS, Gaya AR, Petersen RDS, Gaya A. Trends of underweight, overweight, and obesity in Brazilian children and adolescents. J Pediatr (Rio J). Sociedade Brasileira de Pediatria; 2013;89(5):456-61.

8. Ortega FB, Ruiz JR, Castillo MJ, Sjöström M. Physical fitness in childhood and adolescence: a powerful marker of health. Int J Obes. 2008;32(1):1-11.

9. Ortega FB, Sanchez-Lopez M, Solera-Martinez M, Fernandez-Sanchez A, Sjostrom M, Martinez-Vizcaino V. Self-reported and measured cardiorespiratory fitness similarly predict cardiovascular disease risk in young adults. Scand J Med Sci Sports. 2013;23(6):749-57.

10. Falk B. Muscle Strength and Resistance Training in Youth--Do They Affect Cardiovascular Health? Pediatr Exerc Sci. 2016 Feb;28(1):11-5.

11. Gaya AR, Alves A, Aires L, Martins CL, Ribeiro JC, Mota J. Association between time spent in sedentary, moderate to vigorous physical activity, body mass index, cardiorespiratory fitness and blood pressure. Ann Hum Biol. Taylor \& Francis; 2009;36(4):379-87.

12. Gaya a. R, Silva P, Martins C, Gaya A, Ribeiro JC, Mota J. Association of leisure time physical activity and sports competition activities with high blood pressure levels: Study carried out in a sample of portuguese children and adolescents. Child Care Health Dev. 2010;37(3):329-34.

13. Burgos MS, Reuter CP, Possuelo LG, Valim ARDM, Renner JDP, Tornquist L, et al. Obesity parameters as predictors of early development of cardiometabolic risk factors. Cien Saude Colet. 2015;20(8):2381-8.

14. Ortega FB, Ruiz JR, Castillo MJ. Physical activity, physical fitness, and overweight in children and adolescents: evidence from epidemiologic studies. Endocrinol Nutr. Spain; 2013 Oct;60(8):458-69.

15. Mura G, Rocha NBF, Helmich I, Budde H, Machado S, Wegner M, et al. Physical activity interventions in schools for improving lifestyle in European countries. Clin Pract Epidemiol Ment Health. 2015;11(Suppl 1 M5):77-101. 
16. Powell E, Woodfield LA, Nevill AM. Increasing physical activity levels in primary school physical education: The SHARP Principles Model. Prev Med Reports. 2015;3:7-13.

17. Lonsdale C, Rosenkranz RR, Peralta LR, Bennie A, Fahey P, Lubans DR. A systematic review and meta-analysis of interventions designed to increase moderate-to-vigorous physical activity in school physical education lessons. Prev Med. 2013;56(2):152-61.

18. Gaya A, et al. Scientific and Pedagogical Research Projects. The challenge of scientific initiation. Casa da Educação Física; 2016.

19. Gaya ACA, Gaya AR. Esporte Brasil Project: manual for tests and assessment. Porto Alegre: UFRGS, 2016.

20. Hopkins WG. Measures of reliability in sports medicine and science. Sports Med. 2000;30(1):1-15.

21. Brasil. Secretaria de Educação Fundamental. National curricular parameters: Physical Education/Secretariat of Primary School. - Brasília : MEC/SEF, 1997.

22. Andersen LB, Lauersen JB, Brønd JC, Anderssen SA, Sardinha LB, Steene-Johannessen $\mathrm{J}$, et al. A new approach to define and diagnose cardiometabolic disorder in children. J Diabetes Res. 2015;2015(Cvd):539835.

23. Reuter CP, Rosane De Moura Valim A, Gaya AR, Borges TS, Klinger EI, Possuelo LG, et al. FTO polymorphism, cardiorespiratory fitness, and obesity in Brazilian youth. Am J Hum Biol. 2015.

24. Ruiz JR, Huybrechts I, Cuenca-Garcia M, Artero EG, Labayen I, Meirhaeghe A, et al. Cardiorespiratory fitness and ideal cardiovascular health in European adolescents. Heart. 2014;2:1-8.

25. Farias ES, Carvalho WRG de, Gonçalves EM, Guerra-Júnior G. Effect of programmed physical activity in physical fitness of adolescents. Rev Bras Cineantropom Desempenho Hum. 2010;12(2):98-105.

26. Valenza M, Rodriguez-Torres J, Cabrera-Martos I, Diaz-Pelegrina A, Aguilar-Ferrandiz $\mathrm{M}$, Castellote-Caballero Y. Results of a Pilates exercise program in patients with chronic non-specific low back pain: A randomized controlled trial. Clin Rehabil. 2016.

27. Searle A, Spink M, Ho A, Chuter V. Exercise interventions for the treatment of chronic low back pain: A systematic review and meta-analysis of randomised controlled trials. Clin Rehabil. 2015;10:1-13.

28. Dorneles RCG, Oliveira HL da R, Bergmann ML de A, Bergmann GG. Flexibility and muscle strength/resistance indicators and screening of low back pain in adolescents. Rev Bras Cineantropom Hum. 2016; 18(1); 93-102.

29. Lemes VB, Gaya A, Moreira R, Gaya A. Levels of physical activity in two models of Physical Education classes. Cinergis. 2015;16(4):231-6.

30. Marques KC, Tatiana P, Tornquist D, Muradás R, Lippert N, Burgos LT, et al. Intervention program with physical exercises to improve indicators of physical fitness related to health and motor development of overweight and obese children. Cinergis. 2014;15(3):118-22.

Corresponding

Author

Anelise Reis Gaya

anegaya@gmail.com
Rua Felizardo, 750, Porto Alegre-RS -

zipcode 90690-200

Telephone: +55 (51) 9924-2909
$04 / 08 / 2016$ $05 / 10 / 2016$ $19 / 11 / 2016$ 24/11/2016 